\title{
The Effect of Endorsement and Brand Image on Purchase Decision of Online Culinary Product
}

\author{
Lusiah \\ Department Of Management \\ Universitas Sumatera Utara \\ Medan, Indonesia \\ lusiah79@gmail.com
}

Lorensia Tasya Halim

Department Of Management

Sekolah Tinggi Ilmu Ekonomi IBBI

Medan, Indonesia

lorensia.halim99@gmail.com

\author{
Djatmiko Noviantoro \\ Department Of Management \\ Universitas Tridinanti \\ Palembang, Indonesia \\ djnoviantoro@gmail.com
}

\begin{abstract}
The technology advancement nowadays affect the way people think and people's habit, especially in doing business through online channels by utilizing social media. In the online purchase, one of the many references leading in buying a particular product is from other buyers' review of a product, and sometimes a social media user with many "followers" will "endorse" a particular product. There are few steps leading to buying decision. Buyers (consumers) will be more critical in deciding the product that they want to buy. Thus, a references and image of a certain brand of a product can act as a decision maker for the consumer. The purpose of this study is to determine the effect of endorse and brand image on purchase decisions of online culinary products. This research is a quantitative descriptive research. The populations in this study are the college students in STIE-STMIK IBBI Medan with 347 students as sample. The sampling technique used an accidental sampling method. This research is using Path analysis. The result showing that endorse and brand image has significantly impacted the purchase decision of online culinary product, but in this models endorse has give more dominant impact to purchase decision of online culinary product rather than brand image. Keywords - Endorse; Brand Image; Purchase Decision
\end{abstract}

\section{INTRODUCTION}

The technology advancement nowadays affect the way people think and people's habit, especially in doing business through online channels by utilizing social media [1]. One of the most used social media platform is Instagram. Instagram as a marketing tool becoming a large part of social media strategies applied by companies [2]. It can be seen that in addition to communicating and getting information, culinary promotional activities and sales are popular be sides of fashion trends in social media instagram. This market trend makes every society like to show postings about the culinary he/she was enjoying and not infrequently give additional information such as address or price of the culinary. It cannot be denied also that social media today is the most frequent media visited by the community, thus becoming an effective media for business activities.

In online purchase like on social media Instagram, one of the many references leading in buying a particular product is from other buyers' review of a product and sometimes a social media user like celebrities with many "followers" will "endorse" a particular product. The endorsement is a channel of brand communication in which a celebrity acts as the brand's spokesperson and certifies the brand's claim and position by extending his/her personality, popularity, stature in the society or expertise in the field to the brand [3].

There are few steps leading to buying decision. Buyers (consumers) will be more critical in deciding the product that they want to buy. Thus, a reference and image of a certain brand of a product can act as a decision maker for the consumer. However, according to a survey conducted on 30 consumers who ever made purchases of online culinary product, found that there was an indication that consumers were not satisfied to choose a culinary product they buy from the endorsement that they saw in social media Instagram. Based on the results of the survey authors also can be seen that not all consumers make repeated purchases of these culinary products.

\section{LITERATURE REVIEW}

Endorse

Belch \& Belch [4] defines endorsers as advertisement advocates displayed to convey messages. Endorsers are often referred to as direct sources, is a speaker who delivers a message and or demonstrates a product or service. Specifically, there are five attributes of endorsers consist of Trust worthiness and Expertise which are two dimensions of 
credibility; physical Attractiveness, Respect and Similarity) are components of the general concept of attractiveness (physical attractiveness) [5].

Celebrities attract the attention, create interest in advertisement and create differentiation [6]. From the study it can be concluded that celebrity endorsement creates an impact on consumer buying preference. Celebrity endorsed advertisement are more attractive than non-celebrity endorsed advertisement. Consumers consider that celebrities are reliable, knowledgeable and can influence the demand for the products. Also the study concluded that the products endorsed by the celebrities have more market share. It was found that celebrity endorsement helps to enhance the brand image [7].

\section{Brand Image}

Brand image is perceptions and beliefs held by consumers [8]. As reflected in the association held in consumer memory.By creating the right brand image for a product, it will be very useful for marketers, because the brand image will affect the consumer's assessment of the expected brand alternatives. There are three factors in the formation of brand image: a strength of brand association, the superiority of the brand association, and the uniqueness of brand association [9].

Durrani [10] finds that teenagers buying behavior is correlated and influenced by advertisement, brand loyalty and brand image. There is a practical relation between brand image and teenager consumer's buying behavior. Marketers can come up with carious marketing strategies in to target teenagers in more precise manner. Brand image affects consumer's buying decision and advertisement is a big weapon to attract customers and stay in their minds. This is a real picture of the society that brand image playing a crucial role to change the people's buying behavior [11]. It is suggested that companies that are targeting teenagers should focus more on developing their brand image because it was found that most of the teens were influenced by it [12].

\section{Customer Purchase Decision}

Purchase decision is the election of two or more purchasing alternatives, meaning that one can make decisions, there must be several choices [13]. There are five stages through which consumers make purchasing decisions [8] Problem Recognition, Information Search, Alternative Evaluation, Purchase Decision, and Post Purchase Behavior.

Khan \& Lodhi [14] find that Consumers always try to choose the product that matches with his/her image that is the majority of the respondent preferred style and attractiveness of the celebrity that influence their purchase decision and increase the effectiveness of the celebrity endorsed advertisement. According to the respondents it is concluded that celebrity endorsed advertisements influence on their purchase decision.

Consumer made the purchase decision is influenced by several measurements, namely (1) the measurement of culture, which has the most influence and the most extensive in the behavior of consumers so that marketers need to understand the influence of culture, sub-culture, and social class of consumers; (2) social measurement, which need to be considered when designing a marketing strategy because these factors can affect consumer responses; (3) personal measurements, which consists of the age and stage of life cycle, occupation, economic situation, lifestyle, personality, and self-concept affects the consumer on what is purchased; and (4) psychological measurement, include motivation, perception, learning and beliefs and attitudes also influence the selection of consumer purchases $[13,15]$.

\section{Conceptual Framework}

Based on the literature review about endorse variables, price conformity, and their directly or indirectly influence on brand image and purchasing decisions, the following is the theoretical framework that will be applied in this research:

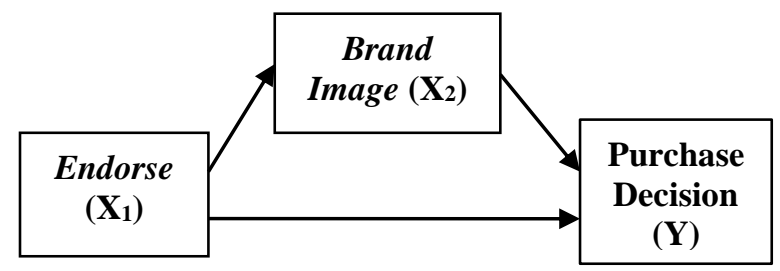

FIGURE 22.1 Conceptual Framework

\section{RESEARCH METHOD}

\section{Population and Samples}

Populations in this research are the active students of STIE and STMIK IBBI in 2015 as much as 2.620 students based on data by Forlap Dikti [16]. The sampling technique in this research is using Slovin formula with the tolerable error rate of 5\% and the result obtained is 347 respondents of active students. To determine the sample used in this research, the researcher used nonprobability sampling technique, which is subjective, based on the availability of respondents, by convenience sampling method or accidental sampling.

\section{Measure of Concept}

This research was a quantitative research. Data analysis technique used in this research is path analysis technique and used of a questionnaire as the instrument of primary data collection. To ensure consistency of the measurement of each item of the questionnaire from the research variables, Validity and reliability of the instruments variable are tested. The questionnaire can be used as a measuring tool if the test meets the requirements of corrected item-total correlation $>0.3$ and Cronbach Alpha $>0.6$.

In measurement model, 13 indicators were used to measure study of latent constructs; purchase decision (5 indicators), brand image (3 indicators) and endorse (5 indicators).

\section{RESULT AND DISCUSSION}

\section{Validity and Reliability Test}

Based on the validity and reliability test on Table 44.1 , the results indicate that each variable is reliable and each 
variable statement is valid, so that the questionnaire can be used as measuring tool to see the effect of endorse and brand image on the decision to buy culinary products online.

TABLE 44.1 Validity and Reliability Result

\begin{tabular}{|c|c|c|c|}
\hline & Endorse & $\begin{array}{c}\text { Brand } \\
\text { Image }\end{array}$ & $\begin{array}{c}\text { Purchase } \\
\text { Decision }\end{array}$ \\
\hline $\begin{array}{c}\text { Cronbach } \\
\text { Alpha }\end{array}$ & 0,782 & 0,807 & 0,808 \\
\hline \multirow{4}{*}{$\begin{array}{c}\text { Corrected Item } \\
\text { Total Correla } \\
\text { tion }\end{array}$} & $\mathrm{E} 1=0,575$ & $\mathrm{BI} 1=0,601$ & $\mathrm{PD} 1=0,617$ \\
\cline { 2 - 4 } & $\mathrm{E} 2=0,553$ & $\mathrm{BI} 2=0,749$ & $\mathrm{PD} 2=0,648$ \\
\cline { 2 - 2 } & $\mathrm{E} 3=0,562$ & $\mathrm{BI}=0,638$ & $\mathrm{PD} 3=0,532$ \\
\cline { 2 - 2 } & $\mathrm{E} 4=0,717$ & & $\mathrm{ED} 4=0,536$ \\
\cline { 2 - 2 } & $\mathrm{E} 5=0,403$ & & $\mathrm{PD}=0,680$ \\
\hline
\end{tabular}

Source: Data Analysis, 2017.

\section{Hypotheses Test}

TABLE 44.2 Correlation Test

\begin{tabular}{|c|r|r|r|}
\hline \multirow{2}{*}{$\begin{array}{c}\text { Latent } \\
\text { Variables }\end{array}$} & \multicolumn{3}{|c|}{ Latent Variable Correlation } \\
\cline { 2 - 4 } & Endorse & Brand Image & $\begin{array}{c}\text { Purchase } \\
\text { Decision }\end{array}$ \\
\hline Endorse & 1 & $0,441^{* *}$ & $0,680^{* *}$ \\
\hline Brand Image & $0,441^{* *}$ & 1 & $0,522^{* *}$ \\
\hline $\begin{array}{c}\text { Purchase } \\
\text { Decision }\end{array}$ & $0,680^{* *}$ & $0,522^{* *}$ & 1 \\
\hline
\end{tabular}

**. Correlation is significant at the 0.01 level (2-tailed).

Source: Data Analysis, 2017.

As can be seen on Table 44.2 above indicates a positive relationship between endorse, brand image and purchase decision of culinary product. The test generated $0.441^{* *}$ in the Spearman Rank Order Correlation Coefficient, which means there is a strong relationship between the endorse and brand image; brand image and purchase decisions $\left(0.522^{* *}\right)$, while a strong relationship exists between the endorse and the purchase decision $(0.680 * *)$.

Based on the correlation test with the Spearman Rank Order Correlation, shows that endorse proved to be an effective marketing tool in marketing a product which in particular in this study is a culinary product. This is also supported by several previous studies $[7,17,18]$.

Furthermore, to see the direct influence and indirect influence between variables, regression between endorse, brand image and purchase decision is performed. The cumulative regression results can be seen in Figure 44.1 below.

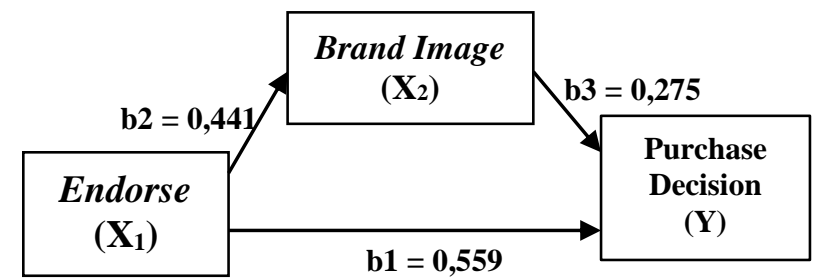

FIGURE 44.1 Latent variable Kelations Frame Work
The result of the coefficient in this model (Table 44.3); where Beta is 0.559 of the endorse and t value is 13,488 \& sig. $<0.05$, which propose that endorse has a significant impact on the purchase decision. Moreover, a Brand image has $\mathrm{t}$ value $6,643 \& \mathrm{sig}$. $<0.05$, therefore, it is further concluded that both brand image and endorse transform has a significant impact on purchase decision as well.

TABLE 44.3 Summary of Result of Test of Hypotheses
\begin{tabular}{|c|r|r|r|r|}
\hline Variable & t-test & F-test & Sig. & R-Square \\
\hline $\begin{array}{c}\text { Brand } \\
\text { Image }\end{array}$ & 6,643 & \multirow{2}{*}{189,351} &, 000 & \\
\cline { 1 - 2 } Endorse & 13,488 & &, 000 & \\
\hline
\end{tabular}

Source: Data Analysis, 2017.

Therefore, $\mathrm{H}_{1}$ is accepted hence it is proved that there is a positive and significant impact of endorse over the purchase decision. Moreover, $\mathrm{H}_{2}$ is also accepted that there is a positive and significant relationship between brand image and purchase decision of online culinary product. Through these results can also be seen that $\mathrm{H}_{3}$ accepted, the value of $\mathrm{F}$ Test of 189.351 with sig. $<0.05$ which means that endorse and a brand image simultaneously affect the decision of purchasing culinary products online. Endorse as a variable that has a more dominant influence in influencing purchasing decisions, and can be seen from the beta value of $55.9 \%$.

TABLE 44.4. Path Analysis

\begin{tabular}{|c|c|c|c|}
\hline & \multicolumn{2}{|c|}{ Causal Effect } & \multirow{2}{*}{ Total } \\
\cline { 2 - 3 } & Direct & $\begin{array}{c}\text { Indirect } \\
\left(\mathbf{X}_{2}\right)\end{array}$ & Effect \\
\hline $\begin{array}{c}\text { Endorse } \rightarrow \\
\text { Purchase Decision }\end{array}$ & 0,559 & $\begin{array}{c}(0,441)(0,275) \\
=0,121\end{array}$ & 0,680 \\
\hline $\begin{array}{c}\text { Brand Image } \rightarrow \\
\text { Purchase Decision }\end{array}$ & 0,275 & - & 0,275 \\
\hline \multicolumn{2}{|c|}{ Total Effect } & $\mathbf{0 , 9 5 5}$ \\
\hline
\end{tabular}

Based on table 44.4 can be observed that the direct effect given by endorse to purchase decision is greater $(55,9 \%)$ compared to brand image $(12,1 \%)$. This shows that consumers will be more interested in buying a product in this culinary product by looking at the endorse of the product compared to the brand of the product.

From the five endorse indicators, the trustworthiness indicator is the highest scoring indicator which means that the consumer purchase because the endorser can provide the trust that about a certain product. The same result which concluded that consumers would assume that endorser is a figure that can be trusted and have knowledge [7]. This means that the endorser will be a person who will change the consumer mindset about a product, which will further help to enhance the image of a product's brand.

Endorse variables also have a direct influence on the brand image. It is also revealed on the results of his research is that Endorsement done by Celebrities has a significant 
influence on the brand image [18]. Some celebrities and brand pairs are chosen to reflect the different types of personalities that each consumer can link and understand and in turn attract to use the product.

The result of R-square test (Table 44.4) shows that endorse and brand image influence purchasing decision by $52,4 \%$. These results indicate that both variables (endorse and brand image) are proven as a strong influencer of purchasing decisions of a product.

\section{CONCLUSION AND SUGGESTION}

Based on the result of the research it can be concluded that Endorse has a more direct contribution or direct influence on the decision to purchase culinary products online. This can be seen from the large percentage of direct influence between endorse variables on purchasing decisions compared with the direct influence of brand image on purchasing decisions and endorse influence on purchasing decisions through brand image. Where then endorse will be more effective to be a marketing tool in influencing the purchase decision of online culinary products than the brand image of the product. Based on the conclusions, for suggestions from the researchers are Endorse gives a more dominant direct influence decision to purchase culinary products online. This indicates that consumers will pay more attention to the endorser compared to the brand of a product. Thus, the company needs to pay attention to the selection of endorsers in which the selected endorser is attractive and has a good image. With successful endorse in attracting consumer buying will indirectly improve the brand image of the product.

\section{References}

[1] Howard, T., Mangold, W. G. \& Johnston, T. Managing your social campaign strategy using Facebook, Twitter, Instagram, YouTube \&Pinterest: An interview with Dana Howard, social media marketing manager. 2014. Business Horizons, 57, 657-665.

[2] Raice, S. \& Spencer, A. E. 2012. Insta-Rich: \$1 Billion for Instagram --- Facebook Inks Its Biggest Deal Ever; Neutralizes Threat from a Hot Photo Start-Up, Wall Street Journal, 1.
[3] Mukherjee Debiprasad. Impact of Celebrity Endorsements on Brand Image. 2009. online retrievedfromusdrinc.com/downloads/CelebrityEndorsement on 13/5/2015.

[4] Belch, George E and Belch, Michael A. "Advertising and Promotion: An Integrated Marketing Communications Perspective". 2009. Edisi ke 8 .

[5] A, Shimp Terence. "Periklanan Promosi dan Aspek Tambahan Komunikasi Pemasaran Terpadu". 2003. Edisi V, Erlangga, Jakarta.

[6] Ingavale, Deepa. Celebrity Endorsement of Cosmetics: a Study of Consumer's Perception and Buying Preferences. Indian Journal Of Applied Research. Volume : 6 | Issue : 2 | February 2016 | ISSN 2249-555X

[7] Anjum, D., Dhanda, S. K., \&Nagra, S.Impact Of Celebrity Endored Advertisments On Consumers. Asia Pacific Journal of Marketing \& Management Review. Vol.1 No. 2, October 2012, ISSN 2319-2836

[8] Kotler, Philip and Kevin Lane Keller, 2007, Manajemen Pemasaran, Edisi Kedua Belas, Jilid 1, dialih bahasakan oleh Benjamin Molan, Jakarta: PT Indeks.

[9] Alfian, B. 2012. Pengaruh Citra Merek (Brand Image) Terhadap Pengambilan Keputusan Pembelian Mobil Toyota Kidjang Inova Pada PT. Hadji Kalla Cabang Polman Makasar: SkripsiUniversitas Hasanuddin

[10] Durrani, Baseer Ali, Godil, Danish Iqbal, Bai, Mirza Uzair, Sajid, San. Impact Of Brand Image On Buying Behaviour Among Teenagers" European Scientific Journal, vol.11, No.5 ISSN: $1857-$ 7881, February 2015, http://eujournal.org

[11] Lavneet. Impact of Advertisements and Brand image on Purchase Decision. 2013. Retrieved from www.socialresearchfoundation.com

[12] Contractor, Samir. Brand Image and It's Impact On Buying Behavior. Abhinav International Monthly Refereed Journal of Research in Management \& Technology. Volume 5, Issue 4 (April, 2016). Online ISSN-2320-0073

[13] Schiffman, L. G., \& Kanuk, L. L.Consumer Behavior. 2010. New Jersey: Pearson-Prentice Hall.

[14] Khan, Afsheen \& Samreen Lodhi. Influence Of Celebrity Endorsement On Consumer Purchase Decision: A Case Of Karachi. Imperial Journal of Interdisciplinary Research (IJIR). Vol.2, Issue-1, 2016 ISSN : 2454-1362

[15] Assael, H. Consumer Behavior - A Strategic Approach. 2004. Boston: Houghton Mifflin.

[16] http://forlap.dikti.go.id/

[17] Ingavale, Deepa. Celebrity Endorsement of Cosmetics: a Study of Consumer's Perception and Buying Preferences. Indian Journal Of Applied Research. Volume : 6 | Issue : 2 | February 2016 | ISSN 2249-555X

[18] Sabunlawa, Zohra. Impact Of Celebrity Brand Endorsements On Brand Image and Product Purchase -A Study For Pune Region Of India. International Journal of Research. Business Management (IMPACT: IJRBM) ISSN (E): 2321-886X; ISSN (P): 2347-4572 Vol. 1, Issue 6, Nov 2013, 37-42 